\title{
WOMEN AND BEAUTY IN NOORDIN HASSAN'S PLAYS
}

\author{
Rohani Md. Yousoff \\ rohaniyousoff@gmail.com \\ School of Arts \\ Universiti Malaysia Sabah
}

\begin{abstract}
Sasterawan Negara Dato (Dr.) Noordin Hassan has often been accused of being "women-struck" by critics who do not understand the meaning of beauty other than the physical aspect. The objective e of this paper is to clarify this misconception using the Islamic framework of analysis of the meanings of "women" and "beauty". Noordin understands the need for balance in the life of mankind and the meaning of Divine Feminine to be an attribute of God. Women are neither chattels nor objects of admiration to be displayed by men, rather to be partners in life, mothers of future generations. Through his plays, Noordin has raised the level of women characters as leaders to demonstrate that the capability of mankind is not determined by gender but by the knowledge within. Raised by his mother, surrounded by other women in his growing years, it is no wonder that Noordin finds women of better quality than men, but only women of hasanah.
\end{abstract}

Keywords: women, beauty, divine feminine, Islamic

\section{INTRODUCTION}

Women have long been the inspiration for poets, lyricists, dramatists and novelists alike and the use of women in creative works have often symbolized a deeper and universal meaning. Unfortunately, society in the past has limited the role of women to wife and bearer of children, merely tools to expand the family. The status of women has not been favourable and women have faced greater challenges for them to overcome this and to attain equal status 
in most communities. With a few exceptions, Noordin has portrayed women as intellectual, equal to men in terms of their qualities of leadership and most importantly, closer to God. This is most likely due to the fact that women are less open to temptation and are less inclined to attain wealth and power. The weaknesses of men who look at the physical attributes and the beauty of women are often their downfall. As Siti Zu mentioned "I am told that I am very beautiful. Many that had claimed to be pious also come to witness this beautiful Creation of God" (Saya dikatakan tersangat indah. Banyak orang yang mendakwa diri alim pun datang menonton keindahan Ciptaan Tuhan ini) (Noordin, 2000:57). Noordin has demonstrated this weakness in his plays such as Peran and Cindai through characters that are tempted by the physical beauty of women that have ended in disgrace. Malaysian National Poet Laureate (Sasterawan Negara) Dato' Dr. Noordin Hassan has been accused of being "woman-struck" by theatre critics. This conclusion has arisen from the strong female characters that were featured in plays. Noordin reiterates this in his autobiography, stating that "I have often put women up on pedestals" (kaum wanita sering saya letakkan di kemuncak) (1996b:55). To Noordin woman is the most beautiful creation of God; he specifically written, "To me, the most beautiful creation of God are certain types of women" (Bagi saya makhluk Allah yang paling indah ialah wanitawanita yang tertentu) (1996b:56).

\section{CONCEPT OF WOMEN}

Women as the Eternal Feminine or the Divine Feminine is “...what attracts man to transcendency" (Chevalier \& Gheerbrant, 1996:374). The Holy Qur'an states that women are "...made for you of your own kind" (Surah $A n-N a h l$ 16:72). Hence, the laws on the treatment and the equality of women are affirmed, for "... they (women) have rights similar (to those of their husbands) over them to what is reasonable" (Surah Al-Baqarah 1:228). In his final sermon, Muhammad SAW reminded his ummah, "You have your rights over wives and they have rights over you" (Yusuf Islam, 1995:36). In guarding the chastity of women, “... there must be four witnesses from amongst you against them" (Surah An-Nisa' 4:16). The Qur'an also states that women should be closely guarded and treated gently, "As if they were eggs preserved" (Surah As-Saffat 37:49). Muhammad SAW affirms this as he said, "Do treat you women well and be kind to them, for they are your partners and committed helpers" (Yusuf Islam, 1995:36). In Christianity, “... 
the Virgin Mary, is at its most perfect embodiment..." as she is above all, “...chaste and bright Energy" (Chevalier \& Gheerbrant, 1996:374). Woman being the symbol of a mother is associated with the earth and the sea where both of these elements are "... symbols of the mother's body" (Chevalier \& Gheerbrant, 1996:677).

\section{CONCEPT OF BEAUTY}

The concept and definition of Beauty have been laboured in different times, from Ancient Greek to Muslim philosophers with not one similar conclusion. In modern times, beauty is limited to the physical aspects. In Islam Majesty ( Jalal) is the exemplar of masculinity, while Beauty ( $\mathrm{Jamal}$ ) is the illustration of femininity. In Islamic poetry the physical attributes of woman that attracts man is Divine Beauty. Aymard and Laude expresses Schuon's statement that, "Beauty (Jamal) is the complementary pole of Majesty (Jalal), as Mercy is that of Rigor" (2004:108). They added:

It expresses itself in a more particular way - in relation to the extrinsic Mercy of Ar-Rahîm - through the quality of Ikram, the "welcoming of benevolent Generosity" that "confers unexpected ascensional graces". Thus Beauty participates in the deepest dimension of the Divine and reveals itself as at one dilating and unifying.

According to al-Ghazali, beauty is divided into the external as perceived by the five senses and internal beauty that can be perceived by the heart (qalb), intellect ('aql) and insight (nür al-basìrah) (Ihya', Vol. 6). Divine Beauty is based on the ninety-nine names and attributes of Allah SWT or asmāullah al-husnā and these attributes are manifested when reflected in human beings (Burrell \& Nazeh, 2007:149). In fact, all these attributes are already reflected in man when God created him. As stated in the Qur'an, "Verily, We created man in the best stature" (Surah At-Tin 95:4). God is beautiful and He loves beauty and beautiful people are people of good character and "Allah loves Al-Muhsinun (good-doers)" (Surah Al-Baqarah 1:195). With beauty comes love and al-Ghazali insists that love comes from a heart that has knowledge and perfection (ibid). He propounds that love is the fruit of knowledge ( $m a$ 'rifa) and love amplifies with the increase of idra' (understanding and knowledge) (al-Ghazali, 2000: Vol 12). Hence, to know God is to know love, for the highest level of love is mahabbah which 
is stronger than the pleasures of life, the external pleasures based on the five senses. On the understanding of beauty by Frithjof Schuon, Aymard and Laude propound:

Beauty is the meeting place-in Perfection-of Absoluteness and Infinitude, the second being reflected in the mysterious character of beauty and the first in its formal regularity"

(2004:108-09).

The Holy Prophet Muhammad was reported to have said, "The whole world is a provision, and the best object of benefit of the world is the pious woman" (Saddiqi, 2000: 907). Schuon reminds us that, “... it would be wrong to conceive of the importance of beauty only as a concession to the world, namely to human weakness" (Aymard \& Laude, 2004:123).

\section{NOORDIN'S WOMEN OF BEAUTY}

According to Noordin, beauty is not only in the physical sense but also in the character of woman as well as her intellect. He had repeatedly mentioned, ${ }^{1}$ that a woman has inner strength, which is not aggressive and obvious as in the physical strength of a man. The personality and convictions of a truly good woman can turn her into a motivator: the kind of motivation that would change circumstances; the kind of motivation which is exemplary not only to women but the community. To numerous other people who need to classify and categorise, it would be feminism. In giving his women characters this kind of strength, Noordin has brought the level of beauty of woman to that of "morally beautiful" and "intelligently beautiful". In his review of Sabri Yunus' telemovie entitled "Sanggul Beracun" Noordin discusses the main character, Siti Aminah, who was born disfigured, but is beautiful to God. ${ }^{2}$ As Siti Zu in Disentuh Bulan Pun said, "It is said that God is Beautiful and loves Beauty"3 (Noordin, 2000:57). All goodness comes with grace. In discussing women and beauty in Noordin's plays, "The feminine theophany must be comprised in the most general framework of the theomorphic character of humanity" (Aymard and Laude, 1996:123). The play of gender role is not an issue.

Apart from four special women (mother, great-grandmother, sisters) strong impressions were made by the women Noordin knew during his childhood, women that supported his imagination through their antics and 
their experiences, women like Mak Gemuk, Mak Tum, Bibi, the beauty of Maini and many others. These women have been the inspirations in creating the characters in his plays. There are also women of minor characters in his plays; minor only in their roles but strong, often stronger than the main characters. As a literary device, there are women who are of not good character, though very few, that are used to emphasise the effect of negative external influences. However, by featuring women as strong characters do not mean that men are not featured as strong characters in Noordin's plays. Yet it would seem that weaknesses of mankind in the abuse of power, greed, jealousy-the antagonists - are mainly male characters. Perhaps it is because men are the ones with power and the temptation is greater. Men were always given the chances to be better educated in comparison to women during the Forties, Fifties and to a lesser degree, as late as the Sixties. Back then, men were expected to support the family and it was thought that the bread-winner must then be given better opportunities. Women were expected to marry, bear and raise children. The "good" male characters, too, have their own strengths, convictions and beauty. It is this attitude that Noordin has successfully challenged his audience in his plays, which some have misconstrued as being "woman-struck". Whether their developments are due to their own initiative, or in more fortunate circumstances (as princesses), the female characters in Noordin's plays do motivate other women to improve themselves and change their situations and positions. This paper will elaborate Noordin's concept of women and beauty through the female characters in their different roles in separate plays. In developing and defining the female characters, Noordin has been guided by the laws as defined in Islam. An Arab proverb says that the intelligence of woman is in her beauty and the beauty of man is his intelligence (Aymard \& Laude, 1996:125), but Noordin refutes this in his portrayal of the female characters in his plays. Not only are the characters women of physical beauty, but al-Muhsinūn (good-doers) with hearts that have the right kind of knowledge. Due to constraints of space, this paper will briefly discuss the women characters in selected plays and delve deeper into the beauty of two main female characters in two plays.

In Sirih Bertepuk Pinang Menari, Noordin reiterates the "similar rights" of women, made "of your own kind" as mentioned above. When Tengku Puteri Kamaliah questions Ihsan why Eve was Created from the left flank of Adam, "...not the head, hand or any other part" (Noordin, 1997b:62). Noordin affirms what is stated in the Holy Qur'an that women are, "From a single person, Created, of like nature," (Surah An-Nisa': 1), an indication 
that women should be treated by men with as much care as other parts of the male body. In another Surah, "That He did create/In pairs-male and female" (Surah Najm 53:45) on which Abdullah Yusuf Ali explains that, "...each sex performs its proper function, and yet its wonderful working is part of the creative process of God..." (Abdullah Yusuf Ali, 1946: footnote no. 5116, 1450). Puteri Kamaliah's knowledge and understanding is that “... women are joined to men. Not superior, not slave, but a friend. And there is no difference in the eyes of God" (Noordin, 1997b: 63). Puteri Kamaliah's beauty is her intellect and courage in leaving her country to save it from the greed of Zahiruddin Syah.

In selecting the name Cindai, Noordin reiterates his belief that women have inner strength, like the cloth cindai, which is soft to the touch but strongly woven. In the play Cindai, a performance is staged at the Corronation (pertabalan) of Tengku Puteri Sharifah Salwa Salamiah as the crown princess (pemangku pemerintah negara) (Noordin, 1997a:11). In the performance Cindai, a court dancer, had been accused of being in an uncompromising situation (bermukah) with Iskandar, and is said to have done this with eight other men. This upsets Tengku Puteri and that night she dreams that Cindai and Iskandar come to inform her that they have been wrongly accused (fitnah). In Islam the offence of fitnah on chaste women is stated in the Qur'an as follows:

And those who accuse chaste women, and produce not four witnesses, flog them with eighty stripes, and reject their testimony forever. They indeed are the fâsiqûn.

(Surah An-Nur 24:4).

Tengku Puteri's strength lies in defying the Wazir who feels that the people should be left ignorant, to preserve the name of the court. She takes it in her stride to change the situation by clearing the good name of Cindai; she goes out to the villages and re-enacts the actual cause of death of Cindai. Despite being a court dancer, Cindai, is not without education, when Pak $\mathrm{Ku}$ asks, "How have you learned to speak in that manner?" She replies, "I learned from the imam at the palace." Although of different backgrounds and status, both of the female characters in this play are beautiful. Tengku Puteri's beauty lies in her strength and courage for righteousness, while Cindai's in her faith in God and the goodness of man. 
Likewise in Bukan Lalang Ditiup Angin, Kintan is strong enough to lead her people from the suppression of Culan. She meets with the men to discuss the rights of the villagers (mainly farmers) who wanted to get out of their positions through violence, but Kintan tells them not to spill blood and not to hate (Noordin, 1996a: $29 \& 38$ ). The beauty in Kintan is her sensibility (perasaannya halus) and Kintan does not act without knowledge for she has studied with Hadi, "Kintan juga bertindak dengan ilmu. Dia belajar dengan Hadi" (Noordin, 1996a: 36 \& 37) also a woman of faith as she replies to Culan who tells her to ask her God (Tanyalah Tuhan kau...). She replies that she does not need to question (God) as she has faith in Him (Aku tak payah menyoal. Aku beriman kepada-Nya) (Noordin 1996a:46). Kintan is a symbolism for a mother or the land and in this play, specifically the country. The play was first staged in 1970, one year after the race riots of 13 May 1969 that left a dark spot in the Malaysian history. She strives for peace and does not believe violence is the solution to the differences between Culan and the farmers. Nevertheless, Kintan is sacrificed, killed by the very bullets she fights against.

Sapura in Anak Tanjung (Noordin, 2006) is another character that symbolizes the country. Her role as the fisherman's wife reflects the state of the Malays before and during the British Occupation of Penang. When she rejects the marriage proposal from her employer, Brown, Noordin is saying that the country rejects the "marriage" of Malaya and England (2006:157). Sapura progresses in confidence as she educates herself and matures, depicting the growth of the nation. Her faith in the power of Allah SWT gives her the confidence to go out to work despite the Japanese soldiers patrolling everywhere. She truly believes that she will be safe as she is protected by Allah SWT and does not need Hamid to accompany her. Noordin expresses that Sapura's strength is in her belief that Allah SWT protects her, a clear assertion of her faith. Sapura's beauty lies in her desire to improve herself and her faith in God.

"Rahimah" is derived from "ar-Rahim," one of the names of Allah (SWT), which means "Merciful" or compassionate. As her name suggests, Intan Siti Rahimah is a compassionate being who cares about the welfare of the villagers. The second wife of Dolah in 1400 (Noordin, 1997a) she is the "jewel" (Intan) of goodness and is used as a vehicle by Noordin to contrast Dolah's wrong-doings. Intan Siti Rahimah sees the truth from her observation, as it corresponds with the reality of the situation in the village. Intan Siti Rahimah spends her time helping the villages and going to the musollah 
(mosque), establishing her search for revealed truth (Al-Haqq). An ousted Siti Rahimah depicts this piety and righteousness when she earns a living making mats, using her knowledge of Islamic motifs as designs of the mats.

The epitomes of beauty of female characters are Nur Atma in Jangan Bunuh Rama-rama (Don't Kill the Butterflies) and Unku Anis in Intan Yang Tercanai (A Polished Jewel). These two are the most enlightened characters in Noordin's plays. Nur Atma begins by offering peace before explaining she is old. However, in his stage directions Noordin explicitly describes the character as around twenty-five years old, basically translated as "Although she is physically old, her eyesight is weak, her ears hard of hearing and her steps not so steady, it is only the sangkar (cage) which is old." The water in the bowl is reduced (Noordin, 2002: 202). In an interview Noordin said "When you rear a bird, you put water in the geluk (bowl) in the bird's cage. When the water finishes, what do you do?"4 The water in the bowl symbolizes the knowledge which is absorbed and has to be replaced with more knowledge as the search for knowledge is endless.

When Nur Atma says she sees the colours changing, it means that through time she has been changed; she is "...charged with a religious quality" (Chevalier \& Cheerbrant, 1996:216). With the additional knowledge that she gains, Nur Atma is being regenerated by being created anew. She has been showered with rain, symbolizing that she has been blessed as rain is a blessing and she is also blown by the wind. According to Chevalier \& Cheerbrant, "...both the Book of Psalms and the Koran equate winds with angels as God's messengers" (111). Nur Atma also has been touched by the moon, and the moon (qamar) is often mentioned in the Holy Qur'an as one of the signs of Allah's SWT powers. ${ }^{5}$ The moon, which does not have its own light, reflects the light of the sun and Nur Atma has been touched and blessed with the power of God's Light. The moon also symbolizes the passing of "...living time, which it measures by its successive and regular phases" (Chevalier \& Gheerbrant, 1996:669).

As Nur Atma II says, "If Atma is not seen here or there, it is all right" (Sekiranya Atma tidak kelihatan di sana sini, tak mengapa) (Noordin, 2002: 202). Even if the moon cannot be seen one knows it is there and if the "soul" is not seen, perhaps it is travelling to another state. Nur Atma has also heard the talkin (last prayers). It seems she has "died" and been reborn, as she repeats, her physical form is old while her soul is not; being "reborn" in the sense of the purification of the soul. As Burckhardt says: 
The mirror of the heart is compared with the moon, which...reflects the light of the sun. The moon is the soul (nafs), which is illumined by the pure Spirit (Ruh), but, being still bound to time, its receptivity has to suffer change (talwin) (119).

According to Corbin (1998), the hermeneutics of symbols (ta'wil or ta 'bir) is the meeting "between God's descent towards the creature and the creature's ascent toward the Creator," as when one meets halfway when crossing a bridge, which "transmutes sensory data and rational concepts into symbols (mazāhir)" which is to say, "to perceive through the figures they manifest and which are the external hexeites" (189). This is what al-"Arabi refers to as "...spirits that take flight beyond matter" (Austin, 2). Yet this encounter cannot happen without Nur Atma's own effort; when God gives, the receiver must have an understanding of his Creator. It is the reciprocity of Allah's love, as 'A'isha r.a reported that the Holy Prophet SAW said, "He who loves to meet Allah, Allah also loves to meet him" ('Abdul Hamid, 2000: Chap. MCXX, 1702).

In accordance with Eliade, "The atman is identified with the entity that is to be found at the heart of man, in the form of "a light in the heart" of Nur Atma (Beane \& Coty, 1975:329). In choosing to name his character Nur Atma, Noordin said he added "Nur" to "Atma" which is a combination of Nur as in "light" and Atma as in "soul". ${ }^{6}$ Guénon explains that Atma is the Universal Spirit (1981:43). As he clarifies, "The "Self" in relation to a being, is properly speaking the Personality." Thus:

The Personality is an immediate determination, primordial and not particularized, of the principle which in Sanskrit is called Ātmā or Paramātmā, and which, in default of a better term, we may call the "Universal Spirit"

(1981:30).

It is reminded that "Spirit" here is not to be taken in the Western understanding of the word. By creating two characters, Nur Atma I and Nur Atma II, Noordin is presenting the two forms, the spiritual and the physical or the Spirit and the Intellect. The use of Nur Atma is best described by Guénon as:

The "Self" as such, is never individualized and cannot become so, for since it must always be considered under the aspect of eternity and immutability which are necessary attributes of pure Being (not susceptible of any particularization) which could cause it to be "other than itself" (1981: 29). Nur Atma has experienced the light which signifies a meeting with the 
ultimate reality when she is conscious of her "self"; she tells Tuk Mah that she is re-born (lahir kembali), which means she has begun life again with her "reserve of vital forces intact, as it was at the moment of birth" (Beane \& Doty, 1975:44). The state of being re-born is symbolic of being cleansed. Eliade explains this process as the beginning of "...life over again with his reserve of vital forces intact, as it was at the moment of birth (ibid). When Nur Atma speaks of being physically young and yet old, Noordin is saying that she has reached another level of existence, a transcendence of the human condition. This puts her in what Guénon describes as the "...two faces of a single reality" (1988:121). The first is the state of "being" and the other in the state of "knowing" which means "the realization of the total being (which) implies total and absolute knowledge" (ibid). Eliade elaborates it as "...not only a metaphysical knowledge translated into terms of rupture and death (it) also implies a consequence of a mystical nature: rebirth to a non-conditional mode of being (which is) absolute freedom" (Beane \& Coty, 1975:312). The light that is with Nur Atma symbolizes ascension of the soul to another plane. As stated in the Qur'an:

Allah is the Light of the heavens and the earth. The parable of His Light is as a niche and within it a lamp: the lamp is in a glass, the glass as it were a brilliant star, lit from a blessed tree, an olive, neither of the east nor of the west, whose oil would almost glow forth, though no fire touched it. Light upon Light! Allah guides to His Light whom He wills.

(Surah An-Nur 24:35).

Nur Atma is beautiful as "Beauty determines or crystallizes the essential Goodness of the Divine" (Aymard and Laude, 1996:109).

In the play Intan Yang Tercanai, Ungku Anis is referred to as a polished jewel (intan tercanai) by her friend, Danial Mubarak. Ungku Anis' willingness to follow Daniel when he carried the kavadi is a relationship which is full of humanism. Ungku Anis understands Daniel's responsibility to fulfil his mother's obligation. But this understanding and sensitivity is not achieved by an ordinary human being unless he or she is "polished" with the knowledge of the Truth (al-Haqq).

It is obvious that Ungku Anis has been educated well in religion as well as Islamic mysticism, to the level of $k a s h f,{ }^{7}$ perhaps, says Noordin. Hujwiri explains kashf as the unveiling or "...destruction of the veiled object" (Nicholson, 4). This means that she has been raised in her level of 
understanding of Islam and through her dhikr is closer to Allah SWT as she has been "unveiled". Burckhardt says that "...there is "for every thing a means of polishing it and freeing it from rust. One thing alone polishes the heart, namely the remembrance of God (whir Allah)'..." (Burckhardt, 118) quoting a saying of the Holy Prophet. As Ungku Anis says on what Daniel thinks of her, “...my personality, my thinking, also my knowledge, truly makes me unusual" (Noordin: Dewan Sastera, 83). As Daniel tells his sister, Sandha, "Her Sheikh ${ }^{8}$ is a descendent of Imam Bukhari. When she was in Singapore, she was close to a descendent of Master Syed Noh." (Noordin, Dewan Sastera, 85). The polished jewel is the symbolism Noordin uses for Ungku Anis whose full name is Ungku Intan Anis. 'Intan' is the Malay word for 'jewel'. This name is also used in Noordin's 1400; Intan Siti Rahimah, the second wife of the rich Dolah, who discards the name 'Intan' after she had leprosy. "A gem, not glass," (Noordin, 1997b:47) says Sultan Idris Bistari about Tengku Puteri Kamaliah, meaning a person of quality. When asked why his choice of the main character is of royal blood, Noordin says he had read about the princess from Kelantan who had just become a magistrate. ${ }^{9}$ The princess could also very well be the same princess that he knew in London that inspired the character of Tengku Puteri Kamaliah in Sirih Bertepuk Pinang Menari. As Yatim says in the closing scene, "Her mind; her intellect; her feelings.

Ungku Anis who has been well educated in religion has also had the opportunity to study abroad, just like Daniel (Nordin, 1997b). During Noordin's days as a student in England, only the rich, elite and the poor yet excellent students (like himself) could afford to study abroad.

It is this understanding that has polished Ungku Anis and has brought the awareness to Daniel until he embraces Islam and chooses the name Danial Mubarak. As Ungku Anis says, "Daniel was searching for a religion that truly convinces him." Noordin voices the changes made to religious traditions which he expresses as "...perhaps created with the right intention, but most likely exaggerated to gallant the ego of that religion (Noordin, Dewan Sastera, 84).

He also made the decision not only because he was awed by Ungku Anis but also, as his sister, Sandha, says, "Danial, is educated. He can think" (ibid). To Noordin, a person who can think, uses his 'aql, who knows "the true nature of this material world" as well as the other that has the "power to understand the secrets of different learning," (Fazlul-Karim, 5) who can 
see the Truth of Islam, as Danial has. Three months after carrying the kavadi to pay penance for his mother, Danial embraced Islam.

Noordin Hassan understands the teachings of Islam and puts his respect for women into practice and further expounds his understanding through his plays, to reiterate the teachings, not to pursue an external feeling but an internal understanding of the workings of God. He understands that beautiful women are those that understand and follow the teachings of the Holy Qur'an, a manifestation of the Goodness of God. This manifestation is not exclusive to any gender as Beauty can be incorporated in man and the first step would be to emulate at least one attribute of Allah SWT.

\section{CONCLUSION}

In analyzing Noordin's dramas it is necessary to look at the strength of the female characters and what they represent. The aspect of beauty in women must be looked from various angles other than the physical beauty. With the knowledge of Noordin's understanding of Islam, the Islamic perspective then applies and Beauty as an emulation of an attribute of Allah SWT brings the level of the female characters to a higher level. The aspects of beauty in the women in Noordin's dramas are intelligence, knowledgeable (worldly and religious knowledge), brave and honourable.

\section{NOTES}

1 Conversations and interviews with Noordin and the author began as early as the 1980s. The author has worked with Noordin as actor, director and producer of his plays for stage and television.

2 Material yet to be published.

3 Researcher's translation. Original lines “Katanya Tuhan itu indah dan suka kepada keindahan".

4 Interview, 30th June, 2009.

5 See, among others, Surahs 10:15, 14: 37, 22: 18, 41: 37.

6 Interview: 21st February, 2008.

7 Kashf: a spiritual state of Islamic Mysticism.

8 Mystic master.

9 Interview: 5th February, 2008. In actual fact Her Highness the Raja Perempuan's name is Tengku Anis and her daughter is Tengku Amalin. 


\section{REFERENCES}

'Abdul Hamid Siddiqi, 2000. Sahīh Muslim. New Delhi: Kitab Bhavan.

Abdullah Yusuf Ali, 1946. The Holy Quran. R.S.A.: Islamic Propagation Centre International.

Al-Ghazālī, 2000. Ihyā' ' 'ulum al-dīn. Beirut: Dāru Sādir.

Al-Hilali, Muhammad Taqi-ud-Din \& Muhsin Khan, Dr. Muhammad (trans.). (n.a.).

The Noble Qur'an in the English Language. Dr. King Fahd Complex KSA:

Islamic University of Al-Madinah Al-Munawwarah.

Austin, R.W.J., 1980. Ibn Al 'Arabi: The Bezels of Wisdom. New Jersey: Paulist Press. Aymard, Jean-Baptise and Laude, Patrick, 2004. Frithjof Schuon: Life and Teachings.

New York: State University of New York.

Beane, Wendall C. and Doty, William G., 1975. Myths, Rites, Symbols: A Mircea Eliade Reader. Vols. 1 \& 2. New York: Harper \& Row.

Burckhardt, Titus, 1987. Mirror of the Intellect. Albany: Albany State University Press.

Burrel, David B. \& Nazeh Daher, 2007. Ghazali: The Ninety-Nine Beautiful Names of God. el Maqsad al-Asnā fĩ Sharh Asmā’ Allah al Husnā. Cambridge: Islamic Texts Society

Chevalier, Jean \& Cheerbrant, Alain, 1996. Symbols. London: Penguin Books.

Corbin, Henry, 1998. Alone with the Alone. New Jersey: Princeton University Press. Guénon, René, 1981. Man and His Becoming. New Delhi: Oriental Books Reprint Publication.

Guénon, René, 1988. The Multiple States of Being. Pakistan, Suhail Academy Lahore. Fazlul-Karim. (trans.), 1985. Imam Ghazzali's Ihya Ulum-Din. Book III. New Delhi: Islamic Book Services.

Muhammad Muhsin Khan (ed.), 1986. Sahīh Al Bukhari. 6th Edition. Lahore: Kazi Publications.

Nicholson, R. A. (trans.), 2006. The Kashfal-Mahjub. New Delhi: Adam Publishers \& Distributors.

Noordin Hassan, 1996a. Bukan Lalang Ditiup Angin. Kuala Lumpur: Dewan Bahasa dan Pustaka.

Noordin Hassan, 1996b. Saya Dari ... Hujung Kota. Kuala Lumpur: Dewan Bahasa dan Pustaka.

Noordin Hassan, 1997a. Peran - Kumpulan Drama. Kuala Lumpur: Dewan Bahasa dan Pustaka.

Noordin Hassan, 1997b. Sirih Bertepuk Pinang Menari. Kuala Lumpur: Dewan Bahasa dan Pustaka.

Noordin Hassan, 2000. Mana Setangginya? Kumpulan Drama Pilihan. Kuala Lumpur: Dewan Bahasa dan Pustaka. 
Noordin Hassan, 2002. Teater Fitrah dan Esei Pilihan. Kuala Lumpur: Dewan Bahasa dan Pustaka.

Noordin Hassan, 2006. ...demi zaitun ... Kuala Lumpur: Dewan Bahasa dan Pustaka. Rohani Md. Yousoff, Noordin Hassan, "Intan Yang Tercanai," in Dewan Sastera, 2009 Jilid 38 Bil. 03. Kuala Lumpur: Dewan Bahasa dan Pustaka.

Yusuf Islam, 1995. The Life of The Last Prophet. Italy: Mountain of Light. 